(1) Nordisk Ministerråd

\title{
HALLO NORDEN ÅRSRAPPORT 2018
}

Efter 20 år skifter Hallo Norden navn til Info Norden 


\section{Hallo Norden - årsrapport 2018}

Efter 20 år skifter Hallo Norden navn til Info Norden

\section{PolitikNord 2019:720}

ISBN 978-92-893-6074-6 (PDF)

ISBN 978-92-893-6075-3 (EPUB)

http://dx.doi.org/10.6027/PN2019-720

(c) Nordisk Ministerråd 2019

Layout: Studio Bjørn Ortmann

Omslagsfoto: Manuel Meurisse / Unsplash

\section{Det nordiske samarbejde}

Det nordiske samarbejde er en af verdens mest omfattende regionale samarbejdsformer. Samarbejdet omfatter Danmark, Finland, Island, Norge og Sverige samt Færøerne, Grønland og Åland.

Det nordiske samarbejde er både politisk, økonomisk og kulturelt forankret, og er en vigtig medspiller $\mathrm{i}$ det europæiske og internationale samarbejde. Det nordiske fællesskab arbejder for et stærkt Norden i et stærkt Europa.

Det nordiske samarbejde ønsker at styrke nordiske og regionale interesser og værdier $i$ en global omverden. Fælles værdier landene imellem er med til at styrke Nordens position som en af verdens mest innovative og konkurrencedygtige regioner.

\section{Nordisk Ministerråd \\ Nordens Hus \\ Ved Stranden 18 \\ 1061 København K \\ www.norden.org}

Download og bestil nordiske publikationer:

www.norden.org/nordpub 
"Arbejdet med at skabe optimale forudsætninger

for at borgere og virksomheder kan bevæge sig frit mellem de nordiske lande er en af det nordiske samarbejdes mest centrale udfordringer."

- De nordiske samarbejdsministres fælles vision for det nordiske samarbejde

Hallo Norden arbejder for at sikre at borgere frit og problemløst kan bevæge sig mellem de nordiske lande for at arbejde, bo eller studere. Hallo Norden er således et konkret værktøj til at virkeliggøre visionen om et grænseløst Norden.

INDHOLD

20 år som informasjonstjeneste

En digital tjeneste for alle i Norden

Hallo Norden samarbejder

Hindringer i det integrerede Norden

Digitalt og mobilt Norden

Hallo Norden på plads

HALLO NORDEN

ÅRSRAPPORT 2018
Jakob Tråsdahl,

Hallo Norden Danmark

Heli Mäkipää,

Hallo Norden Finland

Kate Hammer,

Hallo Norden Færøerne
Pipaluk Lynge-

Rasmussen,

Hallo Norden Grønland Valdís Ösp Árnadóttir,

Hallo Norden Island

Tone Heiene,

Hallo Norden Norge
Anna Sophie Liebst, Hallo Norden Sverige Bent Blomqvist, Hallo Norden Åland Alf Kronvall, Nordisk Ministerråds kommunikationsafdeling 

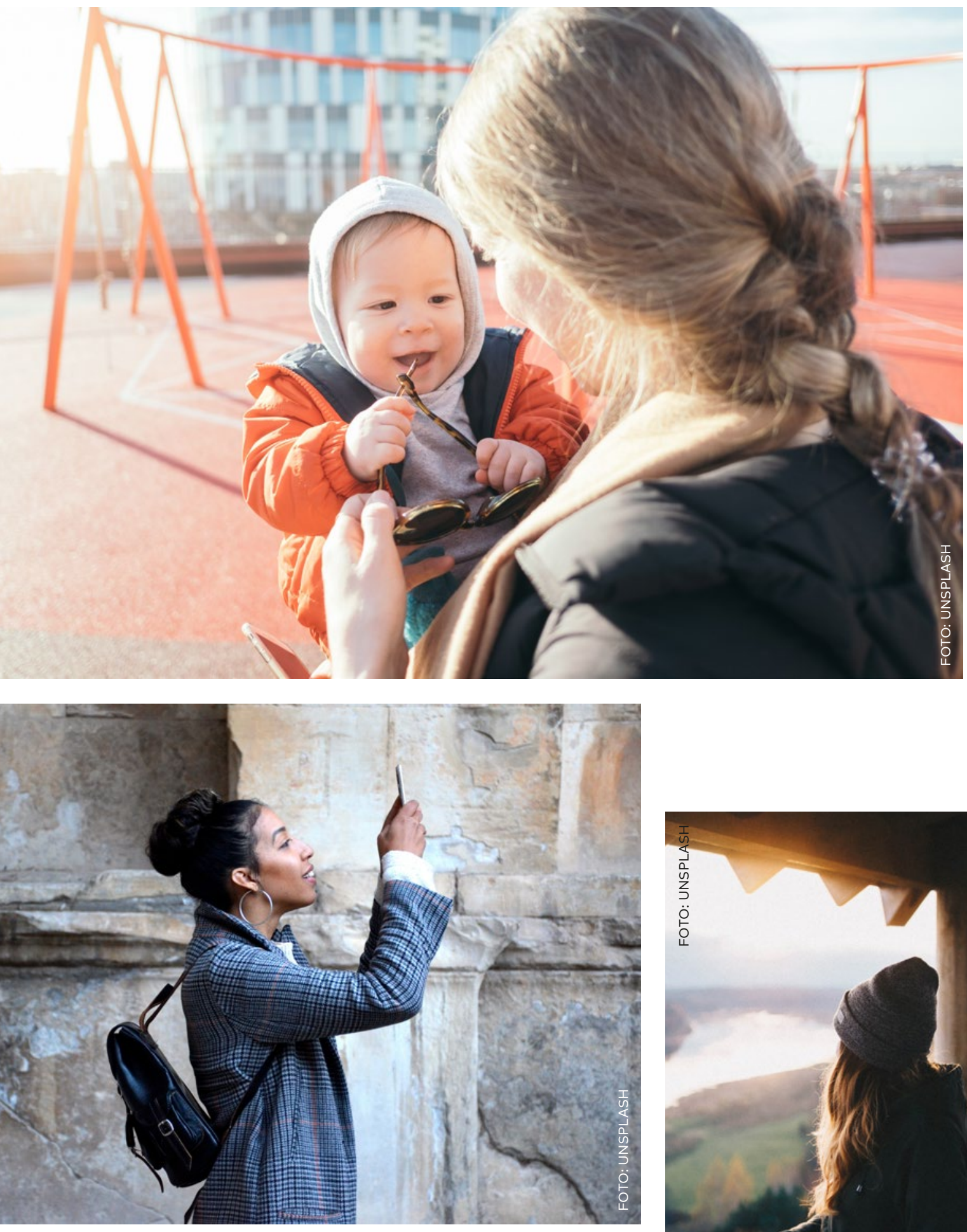
Efter 20 år som Hallo Norden skiftede Nordisk Ministerråds informationstjeneste den 1. januar 2019 navn til Info Norden. Info Norden vil fortsat servicere privatpersoner som vil flytte, arbejde og studere i Norden, men samtidig skal Info Norden også vejlede personer der ønsker oplysninger om at starte og drive virksomhed $i$ et andet nordisk land, give information om nordiske støtteordninger og om det nordiske samarbejde generelt.

Hallo Norden fusionerede i 2018 med webportalen NordSoc, der var de nordiske socialsikringsmyndigheders fælles webportal. Fusionen resulterede i ny og bedre information om social sikring på en lang række områder og i at alle Hallo Nordens artikler nu også kan læses på engelsk.
Hallo Norden stillede i 2018 skarpt på mulighederne for at arbejde og studere i Norden. Det gjorde vi på flere af de nordiske demokratifestivaler, på seminarer og i relevante medier. Desuden var Hallo Norden medarrangør af et seminar om sagsbehandlingstider på socialsikringsområdet henvendt til sagsbehandlere hos de nordiske socialsikringsmyndigheder.

\section{2019 arbejder vi videre under navnet Info Norden og fokuserer på at udvikle og uddybe vores information til de indbygge- re i Norden der ønsker at flytte, arbejde, studere og starte virksomhed i Norden eller søge støtte til nordiske projekter.}

\section{INFO NORDEN}

Hallo Norden er Nordisk Ministerråds informationstjeneste og har eksisteret siden 1998.

Hallo Norden understøtter privatpersoners mobilitet i Norden ved at levere information om at flytte, arbejde eller studere i et andet nordisk land.
Informationstjenesten har otte kontorer. Ét i hver af de nordiske hovedstæder. Tjenesten forvaltes på Færøerne af Nordisk Atlantsamarbejde (NORA), i Grønland af Nordens Institut i Grønland (NAPA) og i Sverige af Nordregio. Alle øvrige kontorer forvaltes nationalt af Foreningen Norden.
Nordisk Ministerråds informationstjeneste skiftede 1. januar 2019 navn til Info Norden og fik samtidig et udvidet mandat, som man kan læse nærmere om i denne rapport.

Info Nordens websider findes på det officielle nordiske samarbejdes website: norden.org/ info-norden. 


\section{0 år som informasjonstjeneste, nytt navn og nye utfordringer}

I 2018 kunne Hallo Norden se tilbake på 20 års arbeid med å gi god informasjon til innbyggerne i Norden. Foreningene Norden og Nordisk ministerråd startet tjenesten i 1998, som et pilotprosjekt ved Foreningen Norden i Sverige. "Hallå Norden" var en nordisk servicetelefon, finansiert av Nordisk ministerråd, med oppgaven å hjelpe dem som fikk problemer med nordisk byråkrati. Etter at prosjektet ble evaluert av Nordisk ministerråd, ble

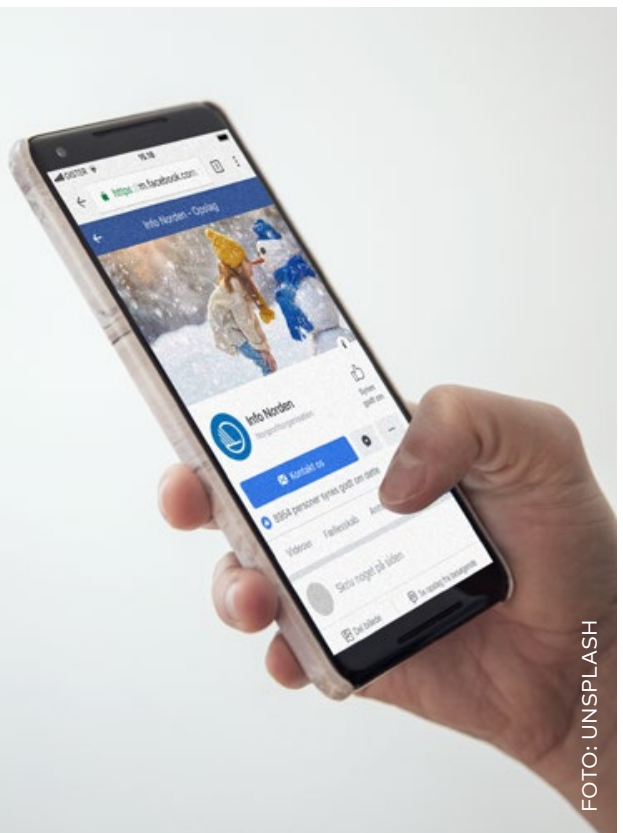

det i 2000 vedtatt at ordningen skulle videreføres med nasjonale løsninger. I løpet av kort tid ble det etablert Hallo Norden-kontorer også i Danmark, Finland, Island og Norge. Da den daværende norske samarbeidsministeren, Jørgen Kosmo, offisielt åpnet det norske kontoret i Stortinget, uttalte han: "Det nordiske samarbeidet er til å for å gjøre livet enklere for innbyggerne i Norden. Hallo Norden skal bidra til å gjøre det enklere, særlig for de som i sin hverdag ferdes over grensene."

Hallo Norden var et av fokusområdene under det finske formannskapet i 2001. Dette året begynte også Hallo Norden å samle inn grensehindre i en felles database. I 2002 lanserte Hallo Norden en webportal som rettet seg til både privatpersoner, foretak og myndigheter. Det ble viktigere å tilby god kvalitetssikret informasjon på de arenaene der folk leter etter dette, nemlig på nettet. Årene siden har det blitt jobbet iherdig med å utvikle nettsidene, og oppdatere disse for å møte de digitale forventningene innbyggerne i Norden har. I desember 2010 ble hallonorden.org nedlagt og all informasjon flyttet over tildet offisielle nordiske nettstedet, norden.org. 


\section{En digital tjeneste for alle i Norden}

Antallet af besøg og henvendelser til Hallo Norden er faldet kraftigt i 2018. Det skyldes i høj grad at Hallo Nordens sider ikke flyttede med da resten af norden.org i efteråret flyttede til nye servere. Det har betydet at Hallo Nordens websider har ligget på et midlertidigt subdomæne, hvilket sammen med andre tekniske udfordringer i forbindelse med flytningen, har påvirket indekseringen af siderne negativt i eksempelvis Google. Grundet arbejdet med de nye websider har annonceringen med Google Ads desuden været sat på pause det meste af 2018. Disse faktorer har betydet at Hallo Nordens websider i 2018 har været mindre synlige i søgemaskiner. Faldet i antallet af besøg og henvendelser har været mest markant i årets sidste måneder, men vi har oplevet et fald igennem hele året.

Eftersom 85 \% af besøgene på Hallo Nordens sider kommer direkte fra søgemaskiner, er antallet af besøg og henvendelser direkte afhængige af synligheden i især Google. I 2019 flytter websiderne igen sammen med resten af norden.org i en ny og bedre løsning der bør sikre bedre optimering mod søgemaskiner, og vi genoptager annonceringen med Google ads.

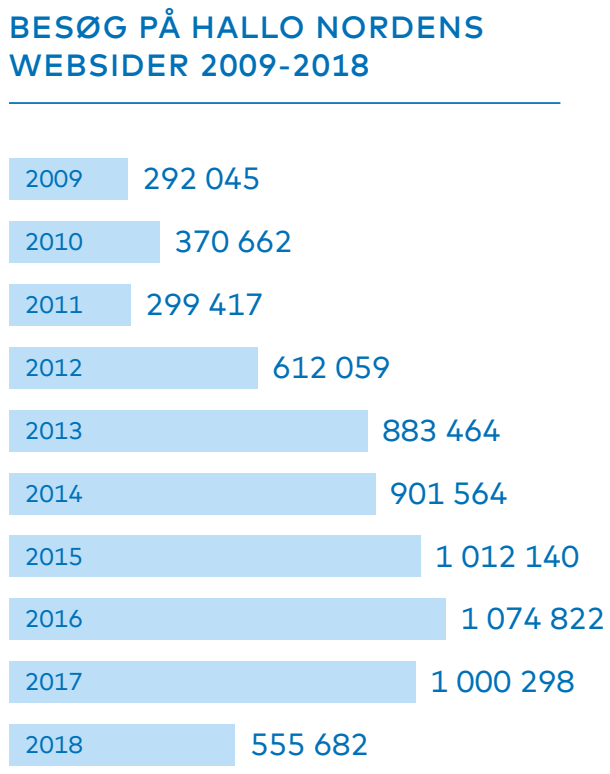

Forbedringer af Hallo Nordens websider Når informationstjenestens websider i 2019 lanceres på det nye norden.org, får brugerne glæde af mere overskuelige artikler og enklere navigation mellem siderne. Desuden findes websiderne nu ikke kun på de fem statsbærende nordiske sprog, men også på engelsk. 


\section{2}

besøg fik Hallo Nordens websider.

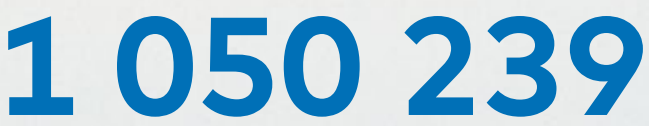

gange blev websiderne vist.

Brugerne besøger gennemsnitligt 1,9 sider. Et besøg varer 112 sekunder.

\section{$84,9 \%$}

af alle besøg kommer direkte fra en søgemaskine.

\section{$0,9 \%$}

af alle besøg kommer fra sociale medier.

\section{$59,1 \%$}

ser siderne på en telefon eller en tablet.

\section{WEB}

Hallo Nordens websider udgør en selvstændig sektion på det nordiske samarbejdes website, norden.org. Hallo Nordens artikler giver letforståelig information af høj kvalitet på dansk, finsk, islandsk, norsk, svensk og engelsk. 


\section{MEST BESØGTE SIDER I LANDENE}

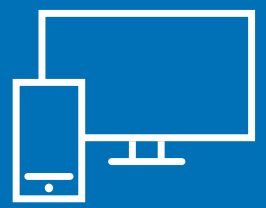

\section{DANMARK}

1. Toldregler i Norge

2. Rejse med kæledyr til Norge

3. Bolig i Norge

4. Flytte fra Danmark til udlandet

5. Dansk statsborgerskab

\section{F/ERØERNE}

1. Bolig på Færøerne

2. Skat på Færøerne

3. Bil på Færøerne

4. Det færøske uddannelsessystem

5. Rejse med kæledyr til og fra Færøerne

\section{ISLAND}

1. Húsnæði í Danmörku (Bolig i Danmark)

2. Húsnæði í Svípjóð (Bolig i Sverige)

3. Atvinnuleit í Danmörku (Jobsøgning i Danmark)

4. Fjárhagsaðstoð til námsmanna frá danska ríkinu (SU)

(Dansk uddannelsesstøtte (SU))

5. Skráning í Pjóðskrá Danmörku

\section{SVERIGE}

1. Tullregler i Norge

2. Resa med husdjur till Norge

3. Resa med husdjur till Danmark

4. Bostad i Norge

5. Medborgarskap i Norge

\section{FINLAND}

1. Tullisäännöt Norjassa (Toldregler i Norge)

2. Työnhaku Norjassa (Jobsøgning i Norge)

3. Lemmikkieläinten tuominen Norjaan (Rejse med kæledyr til Norge)

4. Sairaanhoitajana toimiminen Norjassa (Arbejde som sygeplejerske i Norge)

5. Verotus Norjassa (Skat i Norge)

\section{GRØNLAND}

1. Skat i Grønland

2. Bolig i Grønland

3. Jobsøgning i Grønland

4. Grænsearbejde

5. Flytte fra Danmark til udlandet

\section{NORGE}

1. Tollregler i Sverige

2. Reise med kjæledyr til Danmark

3. Bolig i Sverige

4. Huskeliste når du flytter til Sverige

5. Folkeregistrering i Sverige

\section{ÅLAND}

1. Fordon till Åland

2. Tullregler på Åland

3. Bostad på Åland

4. Införsel av sällskaps- och husdjur till Finland

5. Pensionssystemet i Finland 


\section{HENVENDELSER}

Alle kan stille spørgsmål til Hallo Norden. Det kan gøres via en spørgeformular, telefon eller e-mail. Hallo Nordens opgave er at henvise vores brugere til de rette offentlige myndigheder, websites og publikationer hvor de kan finde svar på deres spørgsmål. Hallo Norden besvarer henvendelser på dansk, finsk, færøsk, grønlandsk, islandsk, norsk, svensk og engelsk.

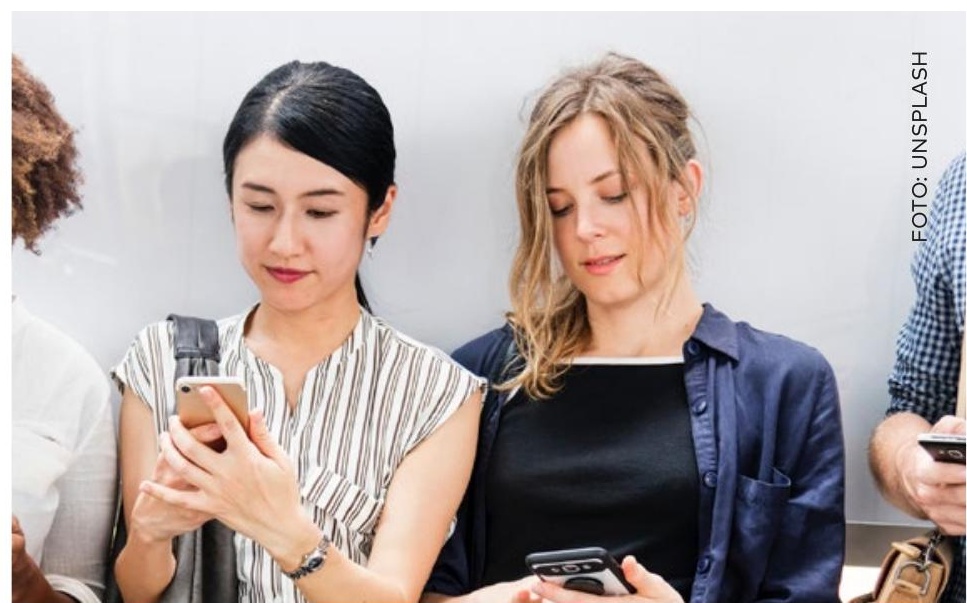

Flytningen af websiderne til et nyt cms-system har været medvirkende til et øget fokus på linkpolicy, formidling, ensartethed og oversættelser. Et arbejde der fortsætter i 2019.

\section{Hvad søger brugerne information om?}

I 2018 fik Hallo Nordens websider 555682 besøg.

De populæreste websider handler fortsat om bolig, jobsøgning, skat, toldregler og at flytte med dyr. I 2018 har Stortingets behandling af nye regler for dobbelt statsborgerskab sandsynligvis været medvirkende til at artiklen om statsborgerskab i Norge har været særlig populær, ligesom det svenske rigsdagsvalg nok er årsagen til at artiklen om stemmeret i Sverige har været særlig populær i 2018.
I 2018 modtog Hallo Norden 1662 henvendelser.

Efter at Norge i flere år har været det land klart flest henvendelser har handlet om, er Sverige nu næsten lige så populært, med Danmark kort efter.

De populæreste emner er fortsat uddannelse, arbejde, skat, folkeregistrering og pension. I 2018 besvarede Hallo Norden flest henvendelser om uddannelse. Der er derudover meget små forskydninger: En lidt større andel af henvendelserne handlede om bil, socialsikringsland og sundhed, mens antallet af henvendelser om børn og barsel, ikke-nordiske borgere og flytte med varer, gods og dyr relativt er faldet en smule.

Al statistik findes i bilaget til rapporten på norden.org/in-rapport. 



\section{FLEST HENVENDELSER OM}

1. Uddannelse

2. Arbejde

3. Skat

4. Folkeregistrering

5. Socialsikringsland

6. Pension

7. Flytteinformation generelt

8. Bolig

9. Ikke-nordiske borgere

10. Bil

11. Børn og barsel

12. Statsborgerskab

13. Sygdom og sundhed

14. Erhverv

15. Bank
ANDEL HENVENDELSER OM

\begin{tabular}{|c|c|c|}
\hline $33,6 \%$ & & Danmark \\
\hline $9,4 \%$ & Finland & \\
\hline $7,4 \%$ & Island & \\
\hline $38,9 \%$ & & Norge \\
\hline $37,7 \%$ & & Sverige \\
\hline
\end{tabular}

Summen er over $100 \%$. Det skyldes at henvendelser ofte drejer sig om flere lande.

HENVENDELSER TIL HALLO NORDEN 2009-2018

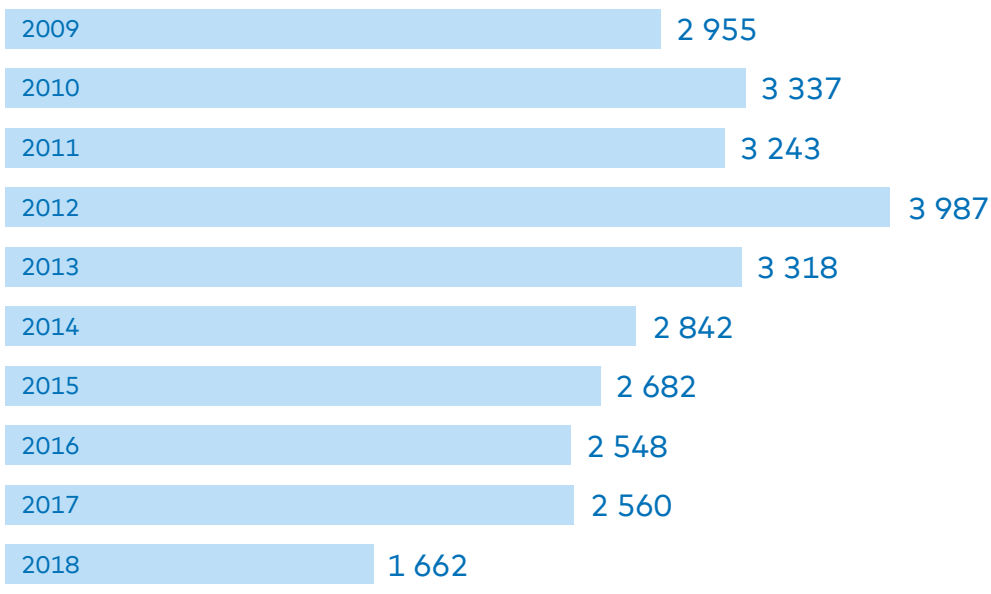




\section{Hallo Norden samarbejder}

\section{Fusion med NordSoc}

I 2018 fusionerede Hallo Norden med de nordiske socialsikringsmyndigheders fælles webportal, NordSoc. Cirka 80 artikler blev publiceret om socialsikring henvendt til dem der arbejder, bor og studerer på tværs af de nordiske landegrænser.

\section{Borgerne i Norden har nu adgang til} udvidet information om socialsikring i en nordisk kontekst med hensyn til alderspension, arbejdsløshedsforsikring, barselsdagpenge, boligstøtte, børnepenge, førtidspension/sjukersättning, pen- sionssystem, rehabilitering, ret til sundhedsydelser, sygedagpenge og ydelser til efterlevende.

Alle artikler findes på de fem nordiske sprog og engelsk. I forbindelse med fusionen udarbejdede myndighederne og Hallo Norden i fællesskab en terminologiliste over alle socialsikringstermer der forekommer i artiklerne. Specifikke termer oversattes af myndighederne til de andre nordiske sprog og til de engelske termer som myndighederne selv anvender på EU-niveau for at sikre ensartethed.

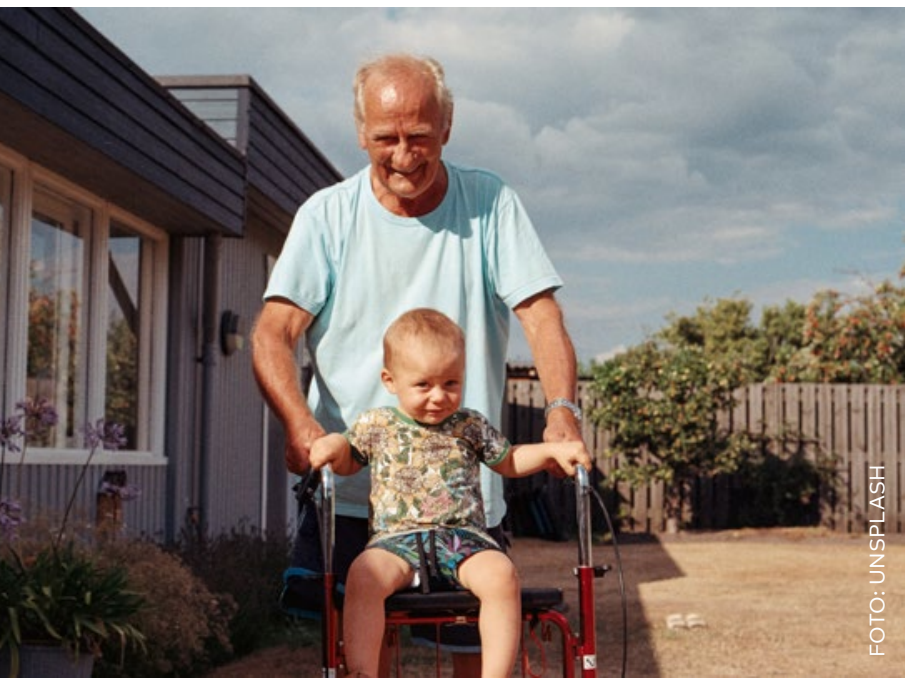

\section{NETVAERK}

Hallo Norden opbygger og vedligeholder et netværk af sagkyndige medarbejdere hos myndigheder og relevante interesseorganisationer, først og fremmest inden for emnerne skat, social sikring, arbejdsmarked, højere uddannelse og erhverv. Dette gør vi for bedst muligt at holde os orienteret om gældende love og regler og for at kunne yde den bedst mulige service til vores brugere. En liste over Hallo Nordens netværk i 2018 findes i bilaget til rapporten på norden.org/in-rapport. 


\section{Hindringer i det integrerede Norden}

For at folk der bor, arbejder og studerer, skal kunne drage nytte af de muligheder der findes i Norden, er det vigtigt at fjerne grænsehindringer der hæmmer en smidig mobilitet mellem de nordiske lande. Hallo Norden bidrager til dette arbejde ved hvert år at indrapportere mulige grænsehindringer som borgerne i Norden støder på, til Grænsehindringsrådets sekretariat.

\section{GRAENSEHINDRINGER \\ Hallo Norden er en væsentlig brik i \\ Nordisk Ministerråds mobilitets- og grænsehindringsarbejde.}

Når borgere henvender sig til Hallo Norden med problemstillinger der kan skyldes en grænsehindring, indsamler vi relevant materiale og indrapporterer det til Grænsehindringsrådets sekretariat. Hallo Norden assisterer desuden Grænsehindringsrådets sekretariat ved planlægning af konferencer og seminarer om grænsehindringer.

Hallo Norden indgår sammen med Grænsehindringsrådets sekretariat og en række grænseregionale informationstjenester og komiteer i netværket LOTS.
Nogle af de cases Hallo Norden indrapporterer, er reelle grænsehindringer, mens andre viser sig at være en anden type af problemer der kan være baseret på forskellige tolkninger af regelværk, fejlagtig information eller forskelle i landenes systemer.

I 2018 indrapporterede Hallo Nordens medarbejdere seks cases til Grænsehindringsrådets sekretariat:

$\rightarrow \quad$ dokumentationskrav for folkeregistrering i Norge

$\rightarrow \quad$ hindring af kunstudbytte mellem Sverige og Åland

$\rightarrow$ manglende kommunikation ved dobbeltstatsborgeres bortgang

$\rightarrow \quad$ ingen godkendelse af nordiske kørekort som legitimation i Sverige

$\rightarrow \quad$ tidskrævende formalia ved grænseoverskridende prøveudtagning af havpattedyr

$\rightarrow \quad$ ændret norsk praksis vedrørende godkendelse af dansk lægeuddannelse.

Grænsehindringsrådet gør en første vurdering om hvorvidt den indrapporterede hindring er en reel grænsehindring eller blot et eksempel på fejlinformation eller udtryk for forskellige landes regel- 


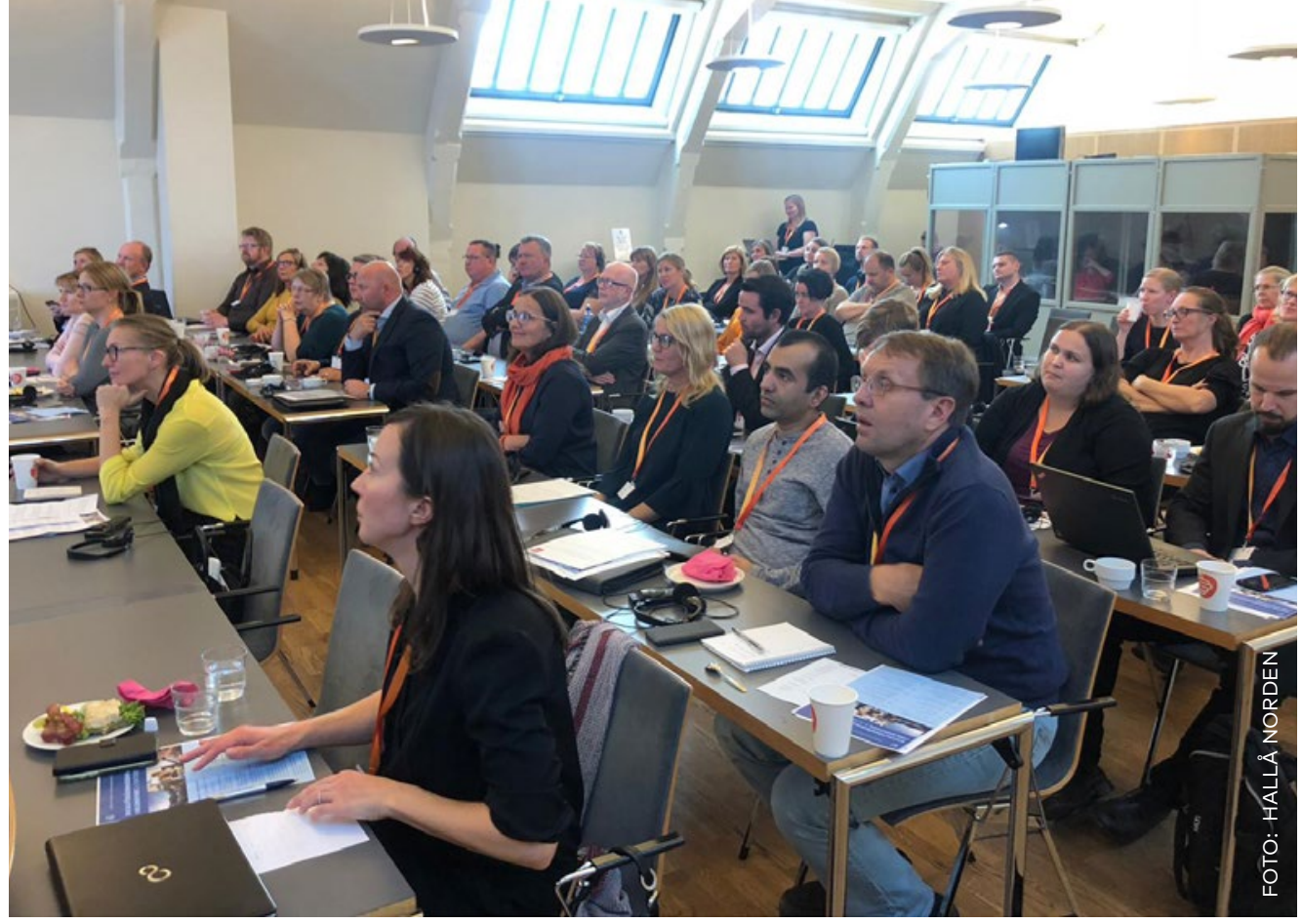

$\uparrow$ Socialförsäkringsseminariet "Ett ännu smidigare myndighetssamarbete" i Helsingfors i oktober.

værk. Hvis hindringen bedømmes at være en grænsehindring, sendes den videre til relevant ministerium som kvalitetssikrer at den indrapporterede hindring faktisk er en grænsehindring samt godkender beskrivelsen af grænsehindringen. Herefter publiceres grænsehindringen i den nordiske grænsehindringsdatabase og beskrives også i Grænsehindringsrådets egen årsrapport.

\section{Problemer i hverdagen i verdens mest inte- grerede region}

Ikke ethvert problem en nordbo støder på, er en grænsehindring, men det betyder ikke at det ikke kan gøre hverdagslivet lidt mere besværligt. I 2018 tog flere borgere

\section{HVAD ER EN GRAENSE- HINDRING?}

Det nordiske samarbejdes definition på en grænsehindring: "Love, offentlige regler eller praksis, der hæmmer individernes mobilitet eller virksomheders evne til at operere på tværs af grænserne i de nordiske lande." At de nordiske lande for eksempel har forskellige skatte- eller socialsikringssystemer, betragtes ikke som en grænsehindring. Men hvis en person på grund af sin mobilitet får dårligere forhold i bopælslandet eller i arbejdslandet end andre personer i en lignende situation, regnes det som en grænsehindring. 
i Norden kontakt til Hallo Norden fordi de stødte på problemer når de ville arbejde, bo eller studere i et andet nordisk land. Her er nogle af de problemer de stødte på:

Begrænsede muligheder for svenske læger at gennemføre klinisk basisuddannelse i udlandet

For at få autorisation som læge i Sverige er det et krav at gennemføre 18 måneders klinisk basisuddannelse (allmäntjänstgöring - AT). Men i Sverige kan højst ni måneder af den mindst 18 måneder lange basisuddannelse krediteres når du gennemfører et AT-forløb i et andet EU- eller EØS-land.

\section{HVAD ER GRANSE-} HINDRINGSRÅDET?

\footnotetext{
Grænsehindringsrådet er et politisk udpeget organ som skal fremme den fri bevægelighed i Norden for enkeltpersoner og virksomheder på vegne af de nordiske regeringer. Formandskabet skifter årligt mellem de nationale medlemmer i Grænsehindringsrådet og følger formandskabet i Nordisk Ministerråd.

Grænsehindringsrådet består af et medlem fra hvert af de nordiske lande samt Færøerne, Grønland og Åland, en repræsentant fra Nordisk Råd og Nordisk Ministerråds generalsekretær. Hvert medlem prioriterer et antal grænsehindringer per år, og rådet følger alle prioriterede grænsehindringer frem til de løses eller afskrives fordi der ikke er politisk vilje til at løse dem.
}

Lang ventetid på D-nummer i Norge skaber problemer ved jobsøgning

Islændinge som søger job i Norge med dagpenge fra Island, kan vente seks uger på at få et D-nummer og blive registreret i Norge som arbejdssøgende, hvilket medfører at de ikke kan modtage dagpenge fra Island i de seks uger hvor de ikke er registreret i Norge.

Skole i Danmark vil ikke godkende uddannelse fra Island

Skolebørn der er flyttet til Danmark fra Island, er i visse situationer blevet sat i en skoleklasse på et lavere klasseniveau. Med argumentet at de ikke har samme kundskaber som deres jævnaldrende danske skolekammerater, er de blevet placeret 1-2 klassetrin under disse kammerater.

Dobbelt statsborgerskab endnu ikke trådt i kraft for Færøerne og Grønland

De nye regler om dobbelt statsborgerskab i den danske lov om indfødsret fra 2014 er endnu ikke trådt i kraft for Færøerne og Grønland. Det betyder for eksempel at en statsborger i et nordisk land der har bopæl på Færøerne eller Grønland, fortsat må give afkald på sine øvrige statsborgerskaber hvis han eller hun ønsker dansk indfødsret gennem ansøgning eller erklæring.

\section{Et smidigere myndighedssamarbejde på socialsikringsområdet på nordisk niveau} Nordisk Ministerråd gennemførte via Hallo Norden og Grænsehindringsrådet i 2018 et socialsikringsseminar om hvordan vi skaber et endnu smidigere myndighedssamarbejde på nordisk niveau. 


\section{BESKRIVELSE AF TO INDRAPPORTEREDE PROBLEMSTILLINGER I 2018}

Hindring af kunstudveksling mellem Sverige og Åland på grund af deponeringsregler for midlertidig import

Kunstmuseer der låner kunst fra øvrige nordiske lande, for eksempel et svensk museum som udstiller ålandske kunstværk, skal i visse situationer deponere moms i modtagerlandet fordi nogle af landene i Norden hører til EU's told- eller skatteområde, mens de øvrige lande i Norden er udenfor told- og skattesamarbejdet.
Nordiske kørekort godkendes ikke som legitimation i Sverige

Flere nordiske borgere støder på problemer når de skal legitimere sig hos visse myndigheder eller private virksomheder i Sverige fordi andre staters kørekort ikke godkendes som ID-legitimation. For eksempel godkender det statsligt ejede selskab PostNord flere forskellige typer af legitimation deriblandt svenske kørekort, men ikke udenlandske kørekort.
Seminaret var et samarbejde med de to finske myndigheder Folkpensionsanstalten og Pensionsskyddscentralen og havde fokus på gældende lovvalg, familieydelser, alderspension og invalidepension.

Deltagerne på seminaret der arbejder som sagsbehandlere på socialsikringsmyndighederne i de nordiske lande fik mulighed for at lytte til europæiske eksperter på socialsikringsområdet samt at deltage i workshops med sine nordiske kolleger for at løse relevante problemstillinger der opstår når de nordiske landes regelværk kolliderer. Formålet med seminaret var at finde løsninger der kan forkorte sagsbehandlingstiderne mellem de nordiske lande. Grænsehindringsrådet og de øvrige interessenter følger fremover op på resultaterne fra seminaret.

\section{Grænsehindringer på agendaen i samar- bejdet med de nordiske ambassader}

De nordiske ambassader i Norge mødtes med Hallo Norden, det norske Grænsehindringsrådsmedlem Vibeke Hammer Madsen, Grænsehindringsrådssekretariatet og det norske Udenrigsministerium for at få information om hvordan vi arbejder med information og grænsehindringer i Norden. Folk der flytter til et andet nordisk land, møder ind imellem problemer, hvilket medarbejderne på de nordiske ambassader også oplever. Et eksempel på et problem som mange støder på, er forskellig håndhævelse af regelværket vedrørende folkeregistrering i Norge. Hallo Norden har i flere år påpeget at det kan virke som om regelværket tolkes forskelligt, da nordiske borgere får forskellige svar på hvad de skal. nordiske landes ambassader i Norge 


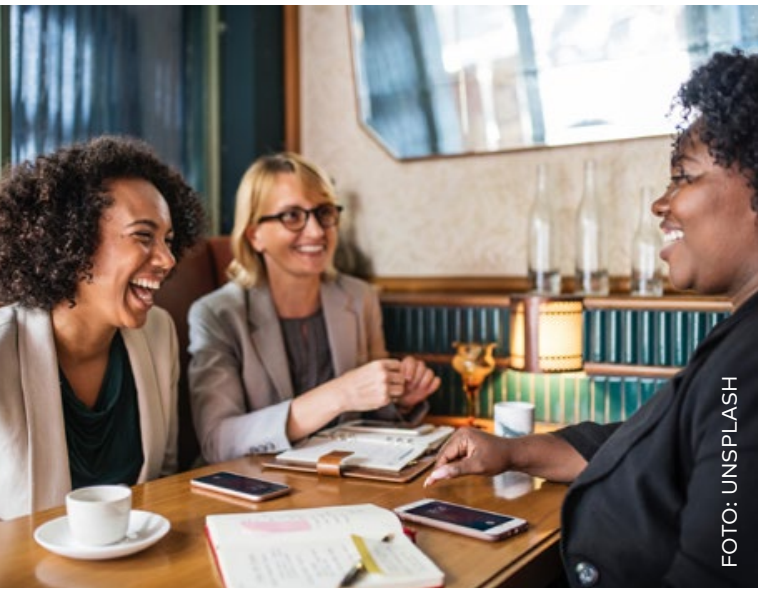

skal i 2019 indsamle nye eksempler på dette til Hallo Norden som vil rapportere det videre til Grænsehindringsrådet.

\section{Norden - lidt mere integreret}

Politikere og embedsmænd i de nordiske lande arbejder hårdt for at Norden skal være verdens mest integrerede region så det bliver lettere at søge arbejde, søge uddannelse og bevæge sig over grænserne. I 2018 blev det lidt lettere at være nordbo i Norden fordi flere grænsehindringer blev løst, og fordi tolkninger af regler og aftaler blev afklaret.

Nordiske unge kan søge ungdomsuddannelse $i$ Norge

Nordiske unge der har ønsket at gå på en ungdomsuddannelse i Norge, har oplevet praktiske problemer, da optagelseskontorerne i de norske fylkeskommuner har tolket kravet til hvornår en ansøger skal have bopæl og være folkeregistreret i

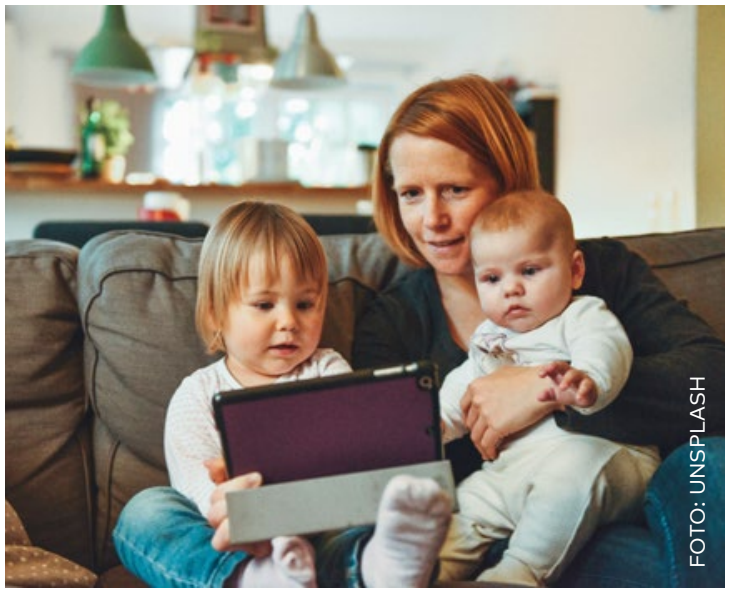

fylket forskelligt. Men Utdanningsdirektoratet i Norge bekendtgjorde i 2018 at "fylkeskommunerne skal behandle nordiske ansøgere som fylkeskommunens egne ansøgere, og kan ikke kræve at en nordisk borger er bosat i fylkeskommunen ved tidspunktet for ansøgningsfristen."

Norge vedtager nye regler for dobbelt statsborgerskab

I december 2018 vedtog Stortinget i Norge nye regler for dobbelt statsborgerskab som ventes at træde i kraft i 2019 eller 2020. Det betyder at ingen nordiske lande derefter vil kræve at en person skal give afkald på tidligere statsborgerskaber hvis de bliver statsborger i et nordisk land ved naturalisation eller gennem erklæring. En statsborger i et nordisk land skal fremover heller ikke give afkald på sit statsborgerskab når vedkommende bliver statsborger i et andet land, medmindre dette lands regler kræver det. 


\section{Digitalt og mobilt Norden}

Sociale medier er vigtige kanaler når Hallo Norden vil være i kontakt med borgerne i Norden. På Hallo Nordens facebookside får Nordens indbyggere løbende information om mulighederne for at arbejde, bo og studere i de andre nordiske lande. De bliver også gjort opmærksom på regler og problemstillinger som de bør have kendskab til når de flytter og pendler i Norden.

På Twitter deler Hallo Norden information om spændende rapporter, seminarer og politikere der beskæftiger sig med den nordiske mobilitet og Norden som verdens mest integrerede region.

Hallo Norden fortsatte i 2018 arbejdet med at producere videoindhold til både Facebook og Twitter da visuelt indhold skaber større brugerengagement og det giver os en mulighed for at vise hvad brugerne kan bruge det nordiske samarbejde og Hallo Norden til.

\section{Nordisk Råd gør livet i Norden lidt enklere!} Hallo Norden producerede otte små film med unge nordboer der stiller spørgsmål til Nordisk Råds politikere om deres arbejde for at gøre Norden til en mere integreret region. Filmene, der inkluderede svar fra politikerne, blev præsenteret på sociale medier op til Nordisk Råds session i
8959

personer synes godt om Hallo Norden på Facebook

1205 personer følger Hallo Norden på Twitter
Oslo og efterfølgende. Diverse shareables med relevant statistik om unge i Norden præsenteredes sideløbende.

\section{Hvilke muligheder skaber mobilitet for unge i Norden?}

I forbindelse med Hallo Nordens seminarer på den svenske Almedalsveckan og den norske Arendalsuka producerede Hallo Norden fire små film med unge nordboer der studerer i et andet nordisk land. De fortalte om de muligheder et studie i et andet nordisk land giver dem, og om de problemer de støder på fordi de studerer i udlandet. Filmene spredtes i hele Norden via sociale medier. 


\section{Hallo Norden på plads}

\section{Informationsturné til sæsonarbejdere i Nordfinland}

Hallo Norden arrangerede i april måned en tre dages informationsturné i finske Lapland i samarbejde med Nordkalottens gränstjänst og Nordjobb. Turnéen gav sæsonarbejderne i regionen information om arbejdsløshedsforsikring, beskatning og social sikring; og informerede erhvervsdrivende om reglerne for at drive virksomhed i de andre nordiske lande og muligheden for at rekruttere nordjobbere.

\section{Demokratifestivalerne i Norden}

Hallo Norden deltog på den ålandske demokratifestival, AlandicaDebatt, der blev gennemført for første gang. I samarbejde med den finske forening Pohjola-Norden arrangerede Hallo Norden en debat om grænsehindringer, muligheder og udfordringer.

Hallo Norden gennemførte sammen med Swedish International Students \& Alumni et seminar på Almedalsveckan i Sverige med rubrikken "Hur kan mobilitet skapa mer möjligheter för unga i Norden och i världen?" Seminaret var yderst velbesøgt og havde fokus på studentermobilitet og de muligheder der findes for unge i Norden. Panelet bestod af personer fra myndigheder og den politiske sfære: Karin Röding, generaldirektör UHR, Agneta Bladh, utredare Internationaliseringsutrednin-

\section{INFORMATIONS- AKTIVITETER}

Hallo Norden vejleder og informerer såvel private, myndigheder organisationer, politikere og beslutningstagere om gældende regler i Norden. Hallo Norden gennemfører hvert år en række informationsaktiviteter rettet mod forskellige målgrupper. Målet er at sætte fokus på mulighederne for mobilitet i Norden.

En liste over Hallo Nordens informationsaktiviteter i 2018 findes i bilaget til rapporten på norden. org/in-rapport.

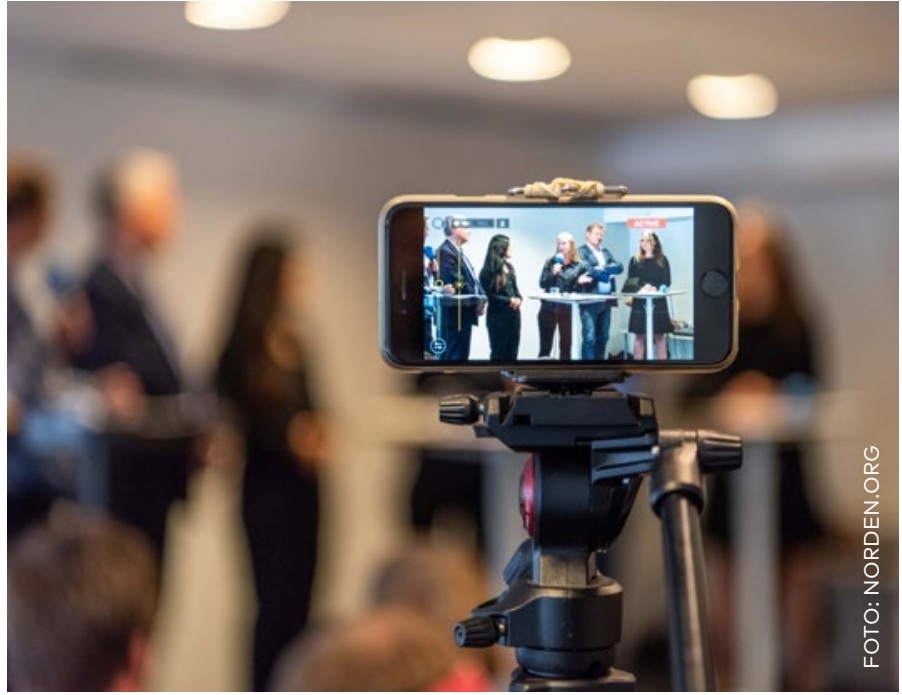

$\uparrow$ Fra debatten om unges mobilitet i Norden under Arendalsuka 
gen, Ole Kristian Bratset, president ANSA, Lars-Arne Staxäng, parlamentariker (M) i Nordisk Råd og moderator Mary Gestrin, Nordisk Ministerråd.

I samarbejde med flere nordiske aktører i Finland planlagde og arrangerede Hallo Norden den nordiske pavillon ved Medborgartorget i Pori i løbet af SuomiAreena-dagene. Den nordiske pavillon var åben i fem dage for alle interesserede og Hallo Norden var på plads for at svare på borgernes spørgsmål.

På Arendalsuka i Norge samarbejdede Hallo Norden med den norske studenterorganisation ANSA om et seminar med rubrikken "Hvilke muligheter skaper mobilitet for unge i Norden?" Panelet bestod af: Rebekka Borsch, statssekretær Kunnskapsdepartementet i Norge, Jorodd Asphjell, stortingsrepræsentant forArbeiderpartiet og Nordisk Råds norske delegation, Mari Sundli Tveit, rektor ved Norges miljø-og biovitenskapelige universitet (NMBU) og formand i Universitets- og høgskolerådet (UHR), Hanna Flood, præsident i Association of Norwegian Students Abroad (ANSA), Dagfinn Høybråten, generalsekretær Nordisk ministerråd samt moderator Ruth Astrid Sæter.

Hallo Norden deltog sammen med Norden i Fokus og Foreningen Norden i Folkemødet Lýsa i Akureyri på Island med et spændende program der ud over at give generel information om det nordiske samarbejde og dets historie blandt andet fokuserede på rigsdagsvalget i Sverige, ligelønscertificering og \#MeToo.

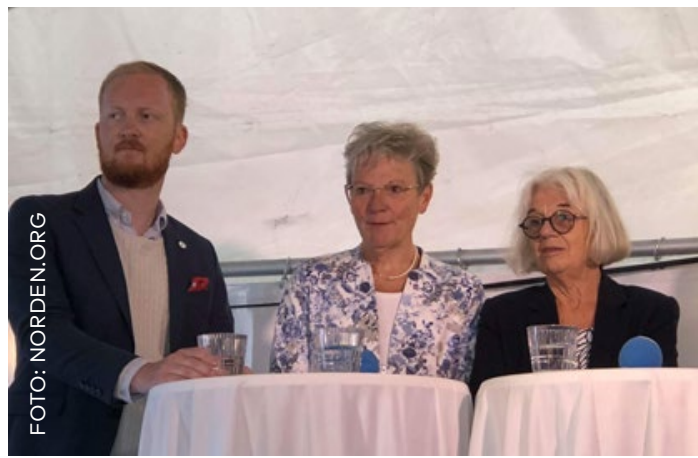

$\uparrow \quad$ Ole Kristian Bratset (ANSA), Karin Röding (UHR) og Agneta Bladh (Internationaliseringsutredningen) diskuterer unges muligheder for mobilitet i Norden på Almedalsveckan

\section{Nordisk Råds session i Oslo}

Hallo Norden bød endnu engang Nordisk Råds politikere på en fantastisk stand med information om alt hvad der er værd at vide om mobilitet i Norden på Nordisk Råds session i Oslo.

Her kunne parlamentarikerne få information om alt hvad man skal tænke på når man vil bo, studere og arbejde i et andet nordisk land, og hvilke problemer borgerne støder på når de faktisk gør det. Parlamentarikerne fik mulighed for at se film med unge der stillede spørgsmål til dem om hvad politikerne gør for at det skal blive lettere at bevæge sig på tværs af de nordiske grænser for at studere eller arbejde.

Hallo Norden bød også på frisk statistik om hvor meget de nordiske lande bruger på uddannelse, hvor mange unge arbejdsløse der er, hvor mange unge der tager en akademisk uddannelse, hvor mange unge der studerer i udlandet, og hvor mange der studerer $i$ et andet nordisk land. 
Nordisk Ministerråd

Nordens Hus

Ved Stranden 18

1061 København K

www.norden.org

\section{Info Norden}

Hallo Norden skiftede i januar 2019 navn til Info Norden.

Vi servicerer fortsat privatpersoner som vil flytte, arbejde og studere i Norden, men samtidig vejleder vi personer der ønsker oplysninger om at starte og drive virksomhed i et andet nordisk land, giver information om nordiske støtteordninger og om det nordiske samarbejde generelt.

Find os på norden.org/info-norden 